\title{
Hosting a professional development day on campus: Engaging nursing student leaders and campus partners
}

\author{
Steven J Palazzo*1, Alissa B Strong ${ }^{2}$ \\ ${ }^{1}$ College of Nursing, Seattle University, United States \\ ${ }^{2}$ Vera Whole Health, United States
}

Received: May 1, 2016

DOI: $10.5430 /$ jnep.v6n11p84

\author{
Accepted: June 26, 2016 \\ Online Published: July 1, 2016 \\ URL: http://dx.doi.org/10.5430/jnep.v6n11p84
}

\begin{abstract}
Experiential learning activities that empower students and engage them in leadership activities are supported by the Institute of Medicine's Report on The Future of Nursing Education. High quality and intense participation in leadership activities can lead to a sense of personal empowerment in students. We describe a partnership between a College of Nursing committee (Student and Community Academic Affairs Committee) and the University's office of Career Services to plan, implement, and evaluate a nursing student led event hosting local recruiters from area hospitals and clinics on campus-Professional Development Day (PDD). All employers surveyed at both events reported that they were "very satisfied" or "satisfied" with the event as well as with the number of students who were a fit for available positions. We found this activity to be a useful venue for the formation of student leaders. In order to further facilitate a "deep learning" process, we would encourage students to get involved in coordinating this event earlier in their education process before their senior year. A step-by-step guide to hosting this type of event is provided.
\end{abstract}

Key Words: Student leadership, Professional development, Nursing students, Engagement, Empowerment

\section{INTRODUCTION}

Experiential learning activities that empower students and engage them in leadership activities are supported by the Institute of Medicine's Report on The Future of Nursing Education. ${ }^{[1]}$ High quality and intense participation in leadership activities can lead to a sense of personal empowerment in students. ${ }^{[2]} \mathrm{New}$ graduate nursing students are expected to enter the profession with leadership qualities that enable them to interact in meaningful ways with members of the care delivery team, the public, and community organizations. Developing opportunities for nursing students to participate in activities that promote engagement in leadership devel- opment is important in undergraduate programs. ${ }^{[3]}$ Gallop released a report of college experiences linked to long-term outcomes. Gallup identified elements of deep experiential learning that matter in graduates' long-term success in work and life and reported that graduates working on long-term projects (typically a semester or more), can apply their learning to a job, and being deeply involved in the extracurricular activity increased their odds of being engaged in work later in life. ${ }^{[4]}$ Employers often search for unique qualities and leadership skills among nursing candidates. The purpose of this descriptive case report is to describe a partnership between a Pacific Northwest College of Nursing student committee

*Correspondence: Steven J Palazzo; Email: palazzos@ seattleu.edu; Address: College of Nursing, Seattle University, United States. 
(Student and Community Affairs Committee) and the University's office of Career Services to plan, implement, and evaluate a nursing student led event hosting local recruiters from area hospitals and clinics on campus-Professional Development Day (PDD).

\section{STUdENT AND COMMUNity AFFAIRS COMMITTEE}

The Student and Community Affairs Committee (SCAC) is a standing committee in the College of Nursing $(\mathrm{CoN})$. The committee consist of at least four faculty members who are appointed by the dean. The chair is elected by committee members to serve a three-year term. Graduate and undergraduate student representatives from the various nursing programs serve on the committee and hold voting privileges. The members include the president of each of the undergraduate cohorts, elected representatives from the graduate programs, and a member of the CoN Student Nurses Association. The total number of members serving on the committee can vary from year to year, but typically includes at least ten active members. Because interest in this committee has grown over the years, attendance at many of the monthly meetings has been much higher than ten. The purpose of the SCAC is to support student and faculty activities within the CoN, university, and community-programs that facilitate positive partnerships with alumni, affiliate agencies, and the community at large. A specific aim of the committee is to develop and promote student leadership and professional development through experiential learning activities guided by faculty mentors. The committee is dedicated to advancing the visibility and positive image of nursing, the college, students, faculty, staff, and alumni through a variety of intra- and inter-college activities. Faculty mentor students in leadership development and provide guidance and structure.

\section{Career services}

Our Career Services office engages students and alumni from six colleges and schools in career planning through career advising, workshops, mentor programs and networking events. Career advisors most often work with nursing students on topics such as resumes, cover letters, and interviewing strategies by presenting workshops, hosting employer speakers, and providing one-on-one career advising. Career Services also presents four career fairs each academic year that are open to all students and alumni. These events typically attract 40-75 employers. Career Services also partners with other departments to assist in the employer management and logistics involved in staging a large career fair.

Originally, Career Services provided basic event support to the $\mathrm{CoN}$ for their PDD. Over the past four years, the $\mathrm{CoN}$ and

Published by Sciedu Press
Career Services have grown their partnership to enhance the essence of professionalism, flow, and employer satisfaction of the event. The event has evolved into a career fair hosting almost 20 employers with more than 100 participants.

\section{Professional development day}

Over the past four years the College of Nursing and Career Services have expanded their partnership to enhance the professionalism and organization of the event while increasing employer satisfaction. Senior nursing students who were members of SCAC were interested in bringing nursing recruiters from several local employers and nursing organizations to campus in an effort to expose nursing students to potential employment opportunities and strengthen students' presentation and interviewing skills. Each year, two nursing students (typically seniors) lead the development, implementation, and evaluation of the annual PDD event. The two student leaders are responsible for facilitating the coordination of activities among the CoN, Career Services office, recruiters from the various regional agencies, and their peer nursing students.

A SCAC faulty member assumed the role of subcommittee lead and facilitated students' leadership development through planning and implementation of the event. The faculty member's role was strictly as a facilitator and guide through the process. The planning process included the following activities: Coordinating the event with Event Services, arranging parking for participants with Public Safety, ordering lunches and beverages through catering services, working with the IT department, marketing the event to students, creating a contact list for potential employer participants and contacting employers (email, letters, phone calls) for involvement, and arranging for student volunteers. To cover the cost of the event, employers were charged a registration fee. These fees are typical of career fairs and cover the cost of the event set-up, meals for recruiters, and online registration fees.

Each year, students were mentored in the areas of professionalism and leadership. In 2014, student members partnered with Career Services to combine employer contact information to ensure that emails and letters were delivered to targeted recruiters and members of nursing organizations. The faculty chair of the committee reviewed correspondence prior to sending and offered constructive feedback to student leaders. Students worked with Career Services to use an employer database in the planning and registration process. Students needed guidance in communicating with the various on campus departments listed above and frequently used the faculty subcommittee lead as a liaison and a source for role modeling professional behaviors. For example, student leaders of the event would seek the advice of the faculty 
chair about how to best approach the various campus services needed to implement the event. The chair would work with students, coaching them on various communication techniques and proper email and interpersonal etiquette.

\section{RESULTS}

\subsection{Student engagement}

The student leaders involved in the planning process for Professional Development Day were engaged in deep experiential learning as well as mentorship from faculty and staff members. Most nursing students already engage in this type of deeper learning in their clinical experiences. Student committee engagement in the Nursing Professional Development Day is a substantial example of extracurricular involvement that allows students to implement a long term project, interact and network with employers, and work with a team of peers. Students used previously learned skills in communication and conflict management to navigate challenging situations with peers and community partners. For example, student leaders had to coordinate the logistics of hosting a large campus held event among invited community members, nursing faculty, staff, students, and administrative personnel; each with competing demands and interest in the project.

In addition to their academics and clinical experiences, this event offered students an opportunity to interact with various offices and personnel on campus to develop additional leadership skills. Employers often search for unique leadership qualities among nursing candidates such as organizational, communication, and teamwork skills. Involving students as leaders of this event is a win-win for both the nursing student as well as employers seeking highly qualified and capable candidates.

We evaluated the effectiveness of the PDD event using extant data. Therefore, IRB approval was not indicated. Permission to use quotes was obtained from the two student leaders who led the 2015 event.

Comments from the two student leaders who led the 2015 event are listed below:

- "I had never had any formal leadership experience so I was frequently questioning what I had gotten myself into. However, through the process of working with faculty, staff, and my peers, I felt prepared and empowered to undertake the process."

- "I was in constant communication with members of [the university] from the get-go and I was able to build professional relationships with some key resources at the university. I organized parking, catering, room set-up, nametags, thank you cards, signage and other event details that were necessary to make PDD the suc- cess that it was. I learned how to delegate while still being involved in the processes to ensure all messages and details were professional and reflected the best qualities of [university] students."

- "I felt empowered by the fact that the faculty and staff that I worked with never took over any of my duties or told me that I wasn't doing what they thought I should do. They all recognized that planning PDD is a student event and they really let the students run with it, while still ensuring they are sufficiently supported."

- "I am a perfectionist, but when planning such a large event, is isn't possible to handle all the details by yourself. I learned that I must assess which resource will be best for each task that needs to be complete and that I must trust in their ability to do so."

- "An important part of our assessment and planning was getting in touch with the best resources-many most appropriately utilized by [university] staff members. It was invaluable to have [faculty chair and Career Services staff] available via email and at times in person to help evaluate our progress and check in about our timeline and assist with brainstorming and strategies along the way. Their presence provided a much-needed quality control measure. At times when I felt stuck, I reached out and communicated about the barrier I had reached or the potential conflict I was facing and [the faculty chair] was surprisingly immediate in his response and always extremely thoughtful and supportive in his communication and action."

- "I always knew that I had people I could turn to for help who wouldn't try to take away, or change, my vision for the event. I learned that collaboration is key and that delegation is necessary."

- "I learned so much about myself, my abilities, my education, my university, and my faculty and peers through planning PDD. The success of this event was a great highlight of my life and something that I will always reflect on and refer back to as a truly fantastic learning experience."

\subsection{Professional development day feedback}

Post event surveys. The Career Services staff created a nine question survey, which was adapted from surveys regularly collected at larger career events on campus. Post event surveys were distributed to employers who attended the PDD in 2014 and 2015. The employer survey was given to employers in paper form as they checked in at the event and collected by student volunteers at the end of the event. Employers had the option of identifying their organization in the surveys. Survey responses were entered into Qualtrics ${ }^{\mathrm{TM}}$ survey soft- 
ware and compiled by Career Services and shared with the CoN.

Thirty-two employers completed the survey. All employers surveyed at both events reported that they were "very satisfied" (84\%) or "satisfied" (16\%) with the event as well as with the number of students who were a fit for available positions. Employers also recommended sending more nurse practitioner candidates to the events. This information will be used when developing the 2016 Professional Development Day.

In addition to measuring employer satisfaction we asked employer participants to list three factors that they felt differentiate a top nursing candidate from other candidates. We then grouped their responses into five categories: interpersonal/leadership skills; preparedness for career/search process; organizational/job fit; personality traits; and academic success. This information can then be shared with faculty and integrated into classroom learning.

After the 2015 event, Career Services emailed an anonymous five question on-line survey (Qualtrics ${ }^{\mathrm{TM}}$ survey software) to 103 students who attended the PDD (identified via a sign-in sheet). Twenty responded to the emailed survey (20\% response rate). Of those 20 participants, $85 \%$ indicated they were "very satisfied" or "satisfied" with the event. When students were asked which organizations or specialty areas were of most interest to them at the event, $88 \%$ of the responses were related to hospitals and medical centers. We did not collect student feedback from the 2014 Professional Development Day.

When students were asked about additional support they would like in the future, the majority were interested in resume and cover letter assistance and follow-up strategies with employers. About half reported they would like support in effectively articulating their skills and experiences to employers. Suggestions included having more hospitals and graduate programs available as well as study abroad options, workshops or conferences that students could attend.

\section{Conclusion}

\subsection{Lessons learned and future directions}

We described an opportunity for nursing students to be actively engaged in the development, implementation, and evaluation of an event overseen by faculty members of a student-faculty nursing committee (SCAC) and personnel from the University's Career Services office. This was a unique opportunity for students to gain firsthand experience with a different skill set than they developed through their clinical and classroom experiences. Employers attending the event were satisfied with the outcomes as were respondents

Published by Sciedu Press to a student post-event survey. The IOM Report on the Future of Nursing emphasizes the importance of developing leaders in undergraduate nursing programs that are ready to assume leadership positions. We found this activity to be a useful venue for the formation of student leaders. In order to further facilitate a "deep learning" process, we would encourage students to get involved in coordinating this event earlier in their education process before their senior year. As event coordinators, they could benefit from interacting with nursing committee members from other cohorts, network with employers earlier on, and have another opportunity to increase their leadership role or learn how to improve the event for the next year. We would also encourage a wider range of student years to attend the event itself, as they can practice networking, gain information of local healthcare facilities, and explore additional ways to build related healthcare experience.

We have provided a checklist below as a reference for nursing schools interested in planning a professional development day on their campus.

\subsection{Developing a nursing professional development day event}

Use this check list to start the implementation process with your campus Career Center or department:

- Determine if there is a database available to house employer information, payments, and correspondence.

- Calculate an event budget and overall costs of catering, room set up, parking, marketing, and other logistics.

- Develop goals for number of attendees and employers for the event.

- Create a list of nursing employers in your region with Human Resource contact information. Use alumni connections and other communications through staff and faculty.

- Consider a registration fee for employers. Create a payment process.

- Decide how the event costs will be funded, including allocation to departments if necessary.

- Delegate clear responsibilities between partner offices and student leaders such as marketing, logistics, and employer correspondence. Encourage feedback and consistent communication.

- Develop timelines of marketing to participants and send employer invitations and reminders.

- Design and distribute marketing materials

- Work with faculty to share the benefits of attending, and create incentives for student attendance.

- Offer a resume and/or "navigating a career fair" preparation workshop 1-2 weeks prior to the event. 
- Recruit student volunteers to assist employers in carrying materials from the parking lot to the event space, check in with attendees, and handle other aspects of logistics.

- Create a survey to measure student and employer satisfaction and solicit feedback. Determine the method of distribution.

- Schedule a debrief meeting to discuss areas of success and growth for the next event.

\section{Conflicts of Interest Disclosure}

The authors declare that they have no conflicts of interest.

\section{REFERENCES}

[1] Medicine IO. 2011. The future of nursing: Leading change, advancing health. Washington, D.C.: The National Academies Press; 2010.

[2] Holden DJ, Crankshaw E, Nimsch C, et al. Quantifying the impact of participation in local tobacco control groups on the psychological empowerment of involved youth. Health Educ Behav. 2004; 31(5):
615-628. http://dx.doi.org/10.1177/1090198104268678

[3] Benner P, Sutphen M, Lenard V, et al. Educating Nurses. A call for radiacal transformation. San Francisco, CA: Jossey-Bass. 2010.

[4] Busteed B. The magical elements of college linked to long-term success in work and life. About Campus. 2015; 19(6): 2-8. http: //dx.doi.org/10.1002/abc.21173 